\title{
REPRESENTATIONAL BACKGROUNDS
}

\begin{tabular}{|c|c|c|}
\hline$\S 1.01$ & $\begin{array}{l}\text { PRODUCT PORTRAYALS } \\
\text { [A] Generally } \\
\text { [B] Mass Media } \\
\text { [C] Doctrinal Linkages }\end{array}$ & $\begin{array}{l}\text { [A] Representational Doctrines } \\
\text { [B] Mixed Theories } \\
\text { [C] Promotional Language as } \\
\text { Interstitial Basis for Liability } \\
\text { [D] Product Appearance }\end{array}$ \\
\hline$\$ 1.02$ & $\begin{array}{l}\text { LINKAGE OF REPRESENTATIONAL AND } \\
\text { NONREPRESENTATIONAL THEORIES }\end{array}$ & \\
\hline
\end{tabular}

\section{$\S 1.01$ PRODUCT PORTRAYALS}

\section{[A] Generally}

There is no single "sesame" password to products liability, but an examination of the way that products are portrayed to the public often provides a powerful tool for analysis. This writer has contended, in a previous work, that judgments of products liability should begin with the portrayal of the product which is made, caused to be made or permitted by the seller. ${ }^{1}$

One must view the concept of product portrayal broadly. The consumer derives his or her impression of a product from various sources, such as advertising, appearance, and the impression built up by widespread social agreement about the product's function. Often, a product representation will be the basis for the theory of liability, as in the instances of express warranty and various tort misrepresentation theories; but the importance of the representation is more pervasive. The representational background of products liability is a subtle, often inadequately appreciated key to judicial decision and proper analysis.

A powerful passage in Judge Traynor's opinion in Greenman v. Yuba Power Products Co. ${ }^{2}$ provides a concrete focal point. He spoke of the "representation"

1 Shapo, A Representational Theory of Consumer Protection: Doctrine. "Function and Legal Liability for Product Disappointment," 60 Va. L. Rev. 1109, 1370 (1974). For judicial reference to this thesis, see Phelps v. Sherwood Medical Indus.. 836 F.2d 296. 298 n.1 (7th Cir. 1987), citing M. Shapo, The Law of Products Liability (1987).

259 Cal. 2d 57, 377 P.2d 897, 27 Cal. Rptr. 697 (1963). 
"[i]mplicit in [a] machine's presence on the market ... that it would safely do the jobs for which it was built." In the context of a consumer's injury caused by a power saw, Judge Traynor declared that "it should not be controlling whether plaintiff selected the machine because of the statements in the brochure, or because of the machine's own appearance of excellence that belied the defect lurking beneath the surface, or because he merely assumed that it would safely do the jobs it was built to do." ${ }^{3}$ Surely, product appearance, in whatever way it works on the consumer mind, is likely to be significant in the determination of liability. An interesting example, involving a product used in industry rather than in the consumer marketplace, appears in a case in which the plaintiffs attributed their injuries to a valve or valves used in an oil well. In reversing directed verdicts for the defendants, the Louisiana Supreme Court concluded, among other findings, that a jury could have decided that one of the valves "was unreasonably dangerous because it appeared to serve the function" of another kind of valve "but failed to do so."

A decision in a very different product context provides another example of the significance of the representational background. This case involved the death of cattle, which allegedly resulted from ingestion of a protein supplement called Golden Flo, made and sold by the defendants. In affirming a judgment for the plaintiff, the court held that there was sufficient evidence to support the verdict, while asking a series of questions involving representations, the justifiability of the plaintiff's actions, and causation. Some additional questions the court posed were:

What representations were made to the plaintiffs, if any, as to the safety of the product and did plaintiff rely upon the representations? Did plaintiffs follow defendants' instructions or recommendations and observe any warnings as to its use? Was plaintiff adequately advised or warned of the possible ill effects of Golden Flo? Was plaintiff justified in feeding Golden Flo as he did for the period of time he did? ${ }^{5}$

Lay as well as legal intuition suggests that the nature of the representation infuses not only the first question but all of these queries.

\section{[B] Mass Media}

It is difficult to overstate the pervasive role of advertising in our society, particularly in mass media. Seller of soap, sex and sandwiches, it is the

3 Id. at 64, 377 P.2d at 901, 27 Cal. Rptr. at 701.

4 Reilly v. Dynamic Exploration, Inc., 571 So. 2d 140, 145 (La. 1990).

5 Center v. National Molasses Co., [1978-1979 Transfer Binder] Prod. Liab. Rep. (CCH) ฯ8313, at 17,578-17,579 (Tenn. Ct. App. 1978). 
principal engine that launches products into the market place. Advertising occupies both background and foreground in our daily existence. ${ }^{6}$

A fascinating example of the importance of the representation in an era of mass media appears in a case involving a toy called "Voltron-Defender of the Universe," described as "a robot-like plastic figure marketed for children four years of age and older." An eight-year-old boy flung a sharp, detachable part of the toy in the direction of a six-year-old neighbor, causing permanent eye injuries. In holding that the plaintiffs complaint survived a motion for summary judgment, a panel of the New York appellate division referred to television cartoons featuring "Voltron, the powerful Defender of the Universe," who "fought enemies with his sword and 'spinning laser blade', a star-shaped weapon with eight sharp points." The court also invoked testimony by experts for the plaintiffs who said that TV shows and videocassettes that depicted "Voltron's use of the spinning blade as an offensive weapon could influence a child, consciously or unconsciously, to emulate such behavior."

In another case involving an unusual fact situation, a suspect grabbed a pistol from a holster worn by a policeman with whom he was struggling and fired a round into the policeman's back. The policeman claimed that it took the suspect "less than five seconds" to get the pistol from the holster, an amount of time that he claimed was "unreasonably short." Focusing on an advertisement that said that the holster, made by the defendant, "positively locks the gun to make snatching extremely difficult from the front, rear, top or side," the court said that "a manufacturer who places an advertisement into the public domain which singles out a specific attribute of their product for praise can fully expect that consumers will read that advertisement and relay the contents thereof to friends and associates." The court commented that "[i]ndeed, creating such a 'buzz' about a product is the very purpose of such advertising."

An interesting example of the influence of media on a specialized area of medical products appears in litigation involving an intrauterine contraceptive device. In refusing to apply the "unavoidably unsafe" classification of comment $\mathrm{k}$ to section 402A of the Second Restatement, the Eighth Circuit commented that an "important factor is that IUD manufacturers, through mass advertising

6 See generally Marshall S. Shapo, "Advertising and the Liability of Product Sellers: Part I," 21 Prod. Safety \& Liab. Rep. (BNA) 510 (1993); Part II, id. at 542 (1993), inter alia synthesizing material from these volumes.

7 Lugo v. LJN Toys Ltd., 146 A.D.2d 168, 169-170, 539 N.Y.S.2d 922, 923-924 (1989), affd, 75 N.Y.2d 850, 852, 552 N.E.2d 162, 163, 552 N.Y.S.2d 914, 915 (1990) (referring to expert evidence that the throwing of the detachable part "was foreseeable because of the extensive television exposure in which Voltron did so").

7.1 Johnson v. Michaels of Oregon Co., Prod. Liab. Rep. (CCH) $\uparrow 18,207$, at 67,138, 2009 WL 458570, at 2-3 (N.D. Miss. Feb. 23, 2009). 
and merchandising practices, generated a general sense of product quality, making it difficult for consumers to fully understand the risks involved with the use of an IUD."

A Michigan court indicated the limits to sellers' responsibility for advertising campaigns in a case in which the plaintiffs sued for injuries, some of them fatal, that they ascribed to the creation and sale of a motorcycle "that could travel and accelerate too fast." Saying that the manufacturer's "claims of speed and fast acceleration in ... advertisements were mostly puffing," the court stressed that the driver of the motorcycle was 26 and licensed to drive the vehicle. $^{9}$

\section{[C] Doctrinal Linkages}

A doctrinally oriented point with important practical consequences is that advertising clearly affects the linkage between the defect issue and the question of whether a product is the "proximate cause" of an accident. This is evident in a case involving a portable air tank that exploded, in which the plaintiff argued that the thinness of the tank caused the accident. In affirming a plaintiffs judgment, the Alaska Supreme Court noted, inter alia, that the manufacturer had advertised that the tank had "thousands of uses" and had said that the product was suitable "for service stations, garages, farms, airports, truckers, etc." The advertising, indeed, had gone so far as to assert that the tank was "absolutely durable ... drop it, kick it ... you can't hurt it!" These claims provided background for an affirmance of the trial court's direction of a verdict against the manufacturer on the "proximate cause" issue. ${ }^{10}$

One should add that manufacturer literature that implies the existence of a risk may create a situation in which a prior lack of warnings generates a case for liability. In a case involving a surgical lamp, the medical provider that purchased the product bought it in 1984, and the plaintiffs injury-severe burns-occurred in 1986. The manufacturer published a document in 1985

8 Hill v. Searle Laboratories, 884 F.2d 1064, 1070 (8th Cir. 1989).

9 Halbrook v. Honda Motor Co., 224 Mich. App. 437, 446, 569 N.W.2d 836, 841 (1997). Cf. Daye v. General Motors Corp., 720 So.2d 654 (La. 1998). This decision denies recovery to a teenager who alleged reliance on a promotional campaign for the "state-of-the-art" braking system on the Corvette automobile, which was advertised as being equipped with brakes that would "never 'lock up' in emergency braking maneuvers." The court concluded that the cause of the plaintiff's accident was his "vigorous application of the brakes while driving through a blind curve on a substandard two-lane country road at a breakneck speed" - 68 miles an hour as he went into the curve. It concluded that the "sole cause" of the accident was the plaintiffs "own negligence due to his excessive speed and his imprudent application of his brakes, not his reliance on [the manufacturer's] promotional information.” Id. at 660 .

10 Dura Corp. v. Harned, 703 P.2d 396, 407 (Alaska 1985). 
that described the product as having a "heat protection filter." There was no reference to that feature in literature published by the manufacturer in 1982, and the design of the product did not change in the intervening three years. In holding that there was a duty to warn about the possibility that a housing on the lamp might be removed, the court employed the 1985 literature as evidence of the manufacturer's awareness of the danger. ${ }^{11}$

It should be noted that a seller cannot employ the protections of an antiSLAPP statute to plead constitutional free speech rights in connection with products claims. The maker of a dietary supplement failed in its effort to assert that its "labeling of and advertising for [its] Product" fell under the statutory language "statement $[\mathrm{s}]$... made in a place open to the public ... in connection with an issue of public interest," given that there was "widespread public interest in dietary supplements generally and in the Product in particular." The court concluded that the "core of the wrongful injury-producing conduct alleged" by the plaintiff was the manufacture and sale of "a defective product that caused ... physical injuries," and opined that the complaint "mirror[ed]" what a precedent had described as speech "largely unrelated to and entirely distinct from the wrongful, injury-causing conduct" alleged by the plaintiff. ${ }^{11.1}$

\section{$\S 1.02$ LINKAGE OF REPRESENTATIONAL AND NONREPRESENTATIONAL THEORIES}

One should note that the representational background of transactions may link theories that are both representationally and nonrepresentationally based.

Even when representations are not the pith of decisions, their influence is often evident. ${ }^{12}$ Indeed, the representational tool may cut in favor of suppliers

11 Witthauer v. Burkhart Roentgen, Inc., 467 N.W.2d 439, 444 (N.D. 1991).

11.1 Brenton v. Metabolife Int'1, Inc., 116 Cal.App.4th 679, 686-687, 10 Cal. Rptr.3d 702, 707, Prod. Liab. Rep. (CCH) 『16,932 (2004) (quoting Martinez v. Metabolife Int’1, Inc., 113 Cal.App.4th 181, 188, 6 Cal.Rptr.3d 494, 499 (2003)).

12 See, e.g., Bonito v. Peekskill Ford Motors, Inc., 64 A.D.2d 682, 683-684, 407 N.Y.S.2d 580, 582-583 (1978) (Suozzi, J., concurring in part and dissenting in part). Despite qualifying language in warranties on a dump truck, Justice Suozzi referred to a brochure picture of a truck with the legend "F-700 Series with Dump Body," the use of order forms with the Ford logotype, and a warranty identification card requesting notification to the dealer to send Ford an address change. He said that when the plaintiff entered the dealer's showroom, "he was contemplating the purchase of a Ford dump truck and had no idea that the dump truck described and displayed to him was anything but a Ford truck." 
against users. ${ }^{13}$ If there is a lesson here for counsel and court, it is that both will do well to look deeper into the images that form consumer perceptions.

\section{[A] Representational Doctrines}

In cases in which the theory of the decision is exclusively representational, the representational background of the directly litigated statement often adds force to holdings of liability. Illustrative is a case imposing express warranty liability against a manufacturer of a transmission. The court noted, inter alia, that the defendant's "Transmission Service Guide," which had been given to the decedent, extolled the virtues of the transmissions and the care and skill with which each one was installed and serviced, and included a picture of the firm's national headquarters. ${ }^{14}$

\section{[B] Mixed Theories}

Multiple doctrines appear against the representational landscape in a case in which the court addressed a variety of theories with respect to a problem involving a sprinkling irrigation system, which was purchased by farmers on the basis of numerous representations in a brochure. Finding express warranties, implied warranties, and negligence in design, manufacture, and installation, the court added that the trial judge's application of the doctrine of strict liability was "not reversible error when considered in light of the facts of the case," which included numerous breakdowns and damage caused by attempts to move the system. ${ }^{15}$ Speaking specifically about the express warranty doctrine, the court cited "well settled" law "that a remote manufacturer without privity with the purchaser is liable for breach of warranty by advertising on radio and television, in newspapers and magazines, and in brochures made available to prospective purchasers, if the purchaser relies on them to his detriment." 16 The court's citation of authority fully supports its holding on the express warranty theory; but beyond that, its articulation of the rule provides important background for its brief declaration of liability on the other doctrines.

13 Thus, one court declared that when a worker orders an electrical plug and does not ask to be told how to wire it, the supplier of the plug has a "right to rely on the implied representation and to assume that the person to whom the plug is supplied will use due care for his own safety and for that of others.” Dulin v. Circle F Indus., Inc., 558 F.2d 456, 466 (8th Cir. 1977) (referring to co-worker of plaintiff's decedent in manufacturer's indemnity action against employer).

14 Scheuler v. Aamco Transmissions, Inc., 1 Kan. App. 2d 525, 527, 571 P.2d 48, 51 (1977).

15 Whitaker v. Farmhand. Inc., 173 Mont. 345, 351, 567 P.2d, 916, 921 (1977).

16 Id. at 353,567 P.2d at 920. 
Broad allegations of negligent or fraudulent promotion or marketing of a drug can provide a basis for showing the commonality of questions of fact and law with respect to class certification. An Ohio appellate court held this way in a case involving several theories of recovery with respect to a prescription drug, in which the plaintiffs sought certification for statewide classes of people injured by the drug. ${ }^{16.1}$

\section{[C] Promotional Language as Interstitial Basis for Liability}

A Washington case, involving the aspiration of baby oil by a 15 -month-old child, demonstrates how the language of product promotion can provide interstitial support for liability claims. Expressing its belief that "the ordinary consumer is unaware of the danger presented by the inhalation of baby oil," the Washington Supreme Court said that "[ $t]$ his misconception is encouraged by the presence of the words 'pure and gentle' on the baby oil container."17

A decision involving allegedly defective nozzles on fire hoses further demonstrates how representations may influence decisions on defect and negligence. The defendant, manufacturer of the nozzles, represented in a pamphlet that its product was "one nozzle for all hose sizes, all patterns, and all flows" and had "the capabilities of making the most of any situation, any hose, or any water supply." This language provided background for the court's denial of summary judgment to the defendant on claims for both strict liability and negligent failure to warn. ${ }^{18}$

A case that arose out of a vehicle rollover stimulated an Oregon decision that representations depicting the vehicle "engaged in sharp steering maneuvers" were sufficient to support a judgment for the plaintiff on the basis of a consumer expectations test. The court noted evidence that the defendant had "specifically marketed" the vehicle as being appropriate "for highway driving" and had "specifically depicted [it] engaging in sharp turns and evasive maneuvers." Thus, although the defendant had not "explicitly represent[ed]

16.1 See Howland v. Purdue Pharma, L.P., Prod. Liab. Rep. (CCH) \16,694, at 59,857-59,858, 2003 WL 21637968, at 4-6 (Ohio Ct. App. July 14, 2003).

17 Ayers v. Johnson \& Johnson Baby Prods. Co., 117 Wash. 2d 747, 765-766, 818 P.2d 1337, 1346 (1991).

18 In re One Meridian Plaza Fire Litig., 1994 WL 161372, Prod. Liab. Rep. $₫ 13,918$, at 44,300 (E.D. Pa. April 29, 1994). Cf. Acosta v. Synthetic Indus., Inc., 88 Cal. App. 4th 944, 106 Cal. Rptr.2d 361 (2001), cert. granted, 111 Cal. Rptr.2d 334 (Cal. 2001). This case dealt with a polypropylene fiber, used as a secondary reinforcer in concrete, which allegedly caused defects in home foundations. In concluding that strict liability would apply to "manufacturers of nonversatile, single purpose products used and incorporated in mass-produced homes," the court observed that the defendant's "promotional materials clearly show that it purports to be expert in the use and application of [the product] as a secondary reinforcer in the construction of concrete structures." 106 Cal. Rptr.2d at 376 . 
that the 1994 4Runner would not roll over under the exact circumstances," the court said that the jury could have found that "an ordinary consumer would reasonably expect a 1994 4Runner traveling at legal speed not to roll over following foreseeable evasive maneuvers, such as three sharp turns on a flat, dry, paved highway." 18.1 The Oregon Supreme Court affirmed, saying that "the controlling test for design defect in Oregon is the consumer expectations test." 18.2

A Sixth Circuit case dealing with a motorbike also illustrates the protean character of advertising representations. The child plaintiff suffered severe injuries when his bike was hit by a pickup truck. He claimed, inter alia, that the bike was defective because it lacked a safety flag. The court affirmed a substantial judgment for the plaintiff despite arguments by the defendant that the trial court improperly admitted an advertisement in which the defendant offered a free "WindWhip" for Christmas with the purchase of one of its motorbikes. The advertisement called the WindWhip a "safety flag for everyone," which "[b]esides being crazy and fun, ... ma[de] younger riders easier to spot." The district court thought that the advertisement was relevant "because the absence of a wind flag was one of the grounds on which plaintiffs rested their strict liability argument." The appellate court concluded that there was no abuse of discretion in admitting the advertisement because it "aided in establishing causation, knowledge, feasibility, and industry standards-issues attendant to Plaintiffs' negligence and strict liability claims." ${ }^{19}$

A case involving an allergic reaction to the additive MSG, contained in vegetable soup served by the defendant restaurant, features language that approaches an express warranty in the background of a decision on a claim for strict liability for failure to warn. In this case the defendant's waitress, questioned by the plaintiff on the point, assured him that the soup did not have MSG. The trial court struck the plaintiff s claim for failure to warn under strict liability on the basis of its finding, as a matter of law, that "there was nothing wrong with ... the MSG in the soup." The appellate court reversed, granting the plaintiff a retrial on his theory that "there was a failure to warn of an ingredient to which a substantial number of the population are allergic." ${ }^{\text {19.1 }}$

18.1 McCathern v. Toyota Motor Corp., 160 Or. App. 201, 224-227, 985 P.2d 804, 818-819 (1999).

18.2332 Or. 59, 79, 23 P.2d 320, 332 (2001).

19 Morales v. American Honda Motor Co., 151 F.3d 500, 516-517 (6th Cir. 1998). See also Ricci v. AB Volvo, 106 Fed. Appx. 573, 576, Prod. Liab. Rep. (CCH) $\$ 17,166$ (9th Cir. 2004) (not for publication) (although appellate court does not decide whether it was an abuse of discretion for trial court not to have instructed the jury in a case involving a vehicle rollover that it "could consider [the manufacturer's] advertising in determining consumer expectations," the instruction "would have been helpful to the jurors ... , and ... it would be appropriate for the judge to grant [the] request" if the question should arise on a remand).

19.1 Livingston v. Marie Callender's, Inc., 72 Cal. App. 4th 830, 85 Cal. Rptr. 2d 528, 534 (1999). 
The "overall message" of promotional material provides a background for a finding that the maker of the Taser device could not get summary judgment on a claim that it had not "adequately warn[ed] against" the risk that the product could cause death. In this federal case, the plaintiff s decedent suffered cardiac arrest after he was hit with a Taser fired in "dart" mode after a struggle with police. There were warnings in documents issued by the manufacturer that "repeatedly cautioned that risk of injury and death is inherent in the circumstances under which Taser devices are likely to be used," and the documents "included various suggestions for minimizing those risks, including avoiding prolonged or excessive discharges of the device against a subject." However, "[t]he warnings did not state that use of a Taser device could in itself cause or contribute to death, suggesting instead that the devices 'have been found to be a safer and more effective alternative when used as directed [compared] to other traditional use of force tools and techniques." In denying summary judgment to Taser, the court noted that "[w]hile Taser's warnings and training discuss sudden in-custody death syndrome at some length, the overall message is that Taser devices are not responsible for such deaths, and that an officer's priority should be to exert control over subjects and place them as necessary in the care of medical professionals as quickly as possible." Declaring that "Taser's warnings are consistent with its view that its devices do not in fact cause or contribute to death in any meaningful sense," the court said it could not "be concluded as a matter of law that Taser adequately warns against the particular risks plaintiffs contend its product pose."19.2

A decision involving a police officer's fatal gunshot injuries, suffered while he wore a bullet-resistant vest, drew on testimony from an officer who was a member of the SWAT team on which the plaintiffs decedent served. This witness recounted a conversation with a representative of the firm that sold the vest to the SWAT team after a bidding process. After asking, "[w] hat is the most powerful weapon that you have to stop?," the sales representative said that the team should purchase a hard armor ceramic insert for their "point man." In fact, it was the plaintiff's decedent who was measured for that product and the team "bought the one vest for him that was supposed to stop" bullets from "the most powerful weapon." The court concluded that this evidence presented a factual issue concerning the warranty of fitness for a particular purpose. $^{20}$

19.2 Salinas v. City of San Jose, Prod. Liab. Rep. (CCH) \18,652, at 69,596, 69,599, 2011 WL 1642475, at 2, 9 (N.D. Cal. May 2, 2011).

20 House v. Armour of Am., Inc., 886 P.2d 542, 554 (Utah Ct. App. 1994). 
A Second Circuit decision draws on a specific product representation to support a theory generally labeled "breach of warranty," pleaded as an alternative to a strict products liability theory. The occasion was a case in which a plaintiff suffered burns when she lost control of a roasting pan that she was gripping by its small handles while cooking a 20-pound turkey. The pan had been "originally manufactured and sold in France as an all-purpose cooking dish without handles," but an American firm had added handles to it to fulfill the request of a television home-shopping channel for a roasting pan to use in a Thanksgiving promotion. An advertisement used in this promotion said that the pan could be used to cook a 25-pound turkey. Without specifically distinguishing among warranty theories - express warranty or implied warranties of merchantability or fitness for a particular purpose - the court concluded that a jury could have found the pan to be defective under breach of warranty instructions on the basis of a "consumer expectations test," even if it had found that the pan's utility was greater than its risk under strict liability. ${ }^{21}$

An advertisement provides the basis for a plaintiff to show a design defect in asbestos products with particular reference to the requirement that the plaintiff show a "feasible safer alternative to the product" at issue. In concluding that there was an alternative product available when the plaintiffs decedent was exposed to asbestos in gaskets made by the defendant, the court refers to an advertisement "with a bold-type headline stating: 'IT'S TIME TO STOP USING ASBESTOS AND NOBOBY HAS BEEN MORE AWARE OF IT THAN GARLOCK."'The advertisement declared that "For handling high pres[sure] and extreme environments, Garlock's asbestos-free gaskets and packing have no equal." As the court summarized the advertisement, it "included additional similar references intended to convey Garlock's belief that its asbestos-free gaskets could accomplish the same functions as its asbestos-containing products." ${ }^{1 . a}$

An interesting variation on the legal classification of product representations appears in a holding that product claims are not protected from express warranty and fraud actions under a so-called anti-SLAPP statute, providing for dismissal of non-meritorious claims based on acts "in furtherance of" a defendant's "right of petition or free speech" under the federal or state

21 Castro v. QVC Network, Inc., 139 F.3d 114, 119 (2d Cir. 1998). A footnote in the court's opinion, which quoted a key New York precedent as well as sections of the Uniform Commercial Code, appeared to focus principally on the implied warranty of merchantability. Id. at 118 n.7, quoting Denny v. Ford Motor Co., 87 N.Y.2d 248, 662 N.E.2d 730, 639 N.Y.S.2d 250 (1995), summarized infra, $926.03[C][2][\mathrm{e}]$, text accompanying notes 84.1-84.7.

21.a Garlock Ceiling Technologies, LLC, Prod. Liab. Rep. (CCH) $₫ 18,637$, at 69,490-69,491, 2011 WL 1811683, at 2-3 (Ky. Ct. App. May 13, 2011) (designated not to be published). 
constitutions "in connection with a public issue." In a suit against a maker of diet products, the court noted that the defendant manufacturer had "cite[d] no authority holding that a manufacturer engages in activity protected by the First Amendment when it produces a product that does not meet its warrantied characteristics, or that a manufacturer engages in activity protected by the First Amendment when it produces a product it knows does not meet its warrantied characteristics."21.1

\section{[D] Product Appearance}

In some cases founded on non-representational doctrines, the appearance of a product may imply a potential for safe use that the facts do not justify. ${ }^{22} \mathrm{~A}$ decision by the Sixth Circuit in an asbestos case provides a subtle example of how the image a product presents may influence a determination that it is defective. Among other allegations, the plaintiff claimed that the defendant, which mined asbestos, had defectively packaged the raw fiber that it sold to users who turned the raw products into goods used in construction. Although the appellate court agreed with a trial court determination that the mining firm "could not be held strictly liable based upon the failure to warn," it declared that "the failure to warn, as well as the defective packaging, were part of "the totality of the circumstances which make [the] product defective." 23

21.1 Martinez v. Metabolife Int'1, Inc., 113 Cal. App.4th 181, 191, 6 Cal. Rptr.3d 494, 501, Prod. Liab. Rep. $(\mathrm{CCH}) \uparrow 16,808$ (2003).

22 See, e.g., Leskey v. Heath Eng'g Co., 293 N.W.2d 39, 40-41 (Minn. 1980) (failure of repair manual to warn that clips on a condenser, "which would appear unimportant to ... ordinary users," should be replaced immediately if broken; since the manufacturer knew that clips might break or be removed in industrial use, it was negligent in failing to warn of the dangers associated with an unsecured condenser). See generally Shapo, supra note 1 , at $1216-1217$.

See also Steffl v. J.I. Case Co., 862 F.2d 692, 694 (8th Cir. 1988) affirming a plaintiff's judgment in a case in which a loader machine, which effectively served as a power shovel, tipped forward, and its bucket trapped the plaintiff's foot against a wall. In holding that it was appropriate to impose strict liability for "failing to warn nonoperating users about the machine's propensity to tip," the court noted that despite such a propensity, "there is nothing about the appearance of the machine to suggest to a user giving directions to an operator that it tends to tip forward when dumping its load."

Cf. King v. Kayak Mfg. Corp., 387 S.E.2d 511(W. Va. 1989). In that case, in which a plaintiff became quadriplegic after a dive into an above-ground swimming pool, the court held it was not error to admit advertising and promotional material that showed people diving into similar pools made by the defendant. The court read several precedents to say that "the manufacturer's suggested uses for a product contained in its advertising or other literature are admissible on the issue of what is an appropriate, intended use of a product." Id. at 523.

23 Adkins v. GAF Corp., 923 F.2d 1225, 1228 (6th Cir. 1991) (quoting 706 F. Supp. 559, 565 (S.D. Ohio 1988)).

Another court refers to product appearance in affirming a punitive damage award. This case involved an object that flew out of an industrial lathe and smashed through a viewing window into the chest of the lathe operator. Affirming the award, the court refers, inter alia, to the fact that the defendant had undertaken "modifications to give the appearance of safety, regardless of whether the lathe was in fact any safer." Groth v. Hyundai Precision \& Indus. Co., 209 Or. App. 781, 149 P.3d 333, 340, Prod. Liab. Rep. (CCH) 917,642 (2006). Cf. Boots v. Stanley Black \& Decker, Inc., Prod. Liab. Rep. (CCH) $₫ 19,698$, at 75,765, 2015 WL 5512777, at 8 (N.D.N.Y. Sept. 16, 
Employing the consumer expectations test embedded in Ohio law, the court affirmed a judgment on the liability issue against the firm.

A Missouri court of appeals referred to the fact that the product Q-Tips were "strenuously promoted as soft and safe" but did not "inherently alert a user to their potentially destructive capacity"-specifically, the danger they posed of causing damage to the inner ear. In a case in which a five-year-old child suffered serious injuries when he stuck a Q-Tip into his ear canal in an effort to clean his ears, the court said that the manufacturer, "by its extensive marketing activity, actively contributed to the consumer perception that Q-Tips were the safest swabs available." The method of promotion of the product thus stood in the foreground of the court's imposition of a duty to warn about the risk of inserting the product into the ear canal. ${ }^{24}$

By parity, properly qualified product portrayal may create a representational background that cuts against liability. A St. Louis dentist who was a high-level racquetball player found this out when he sued the manufacturer of a lensless eye guard for injuries sustained when his opponent's return shot hit him in the eye, causing severe injury. The plaintiff introduced an advertisement in a racquetball magazine that claimed that the product was made from a "tough, virtually indestructible polycarbonate" and would "stop a lot of accidents." However, noting the plaintiffs proficiency at the game, and pointing out that "[ $\mathrm{t}]$ here was no claim in the advertisement that the eye guard would prevent all accidents," the court thought that a jury could conclude that the plaintiff "must have known the hazards that existed notwithstanding his use of the eye guard." 25

2015), in which the plaintiff was injured when he tried to free the blade of a utility knife which had become stuck in a vinyl jamb. The court denies a summary judgment motion on a design defect claim that was based on the idea that the "knife was defectively designed because" icons on the product misled users into believing that the "knife blade was locked in place when it wasn't."

24 Strothkamp v. Chesebrough-Pond's, Inc., Prod. Liab. Rep. (CCH) \13,456, at 41,879-41,880, 1993 WL 79239 (Mo. Ct. App. Mar. 23, 1993) (not for publication), appeal dismissed (1993).

25 Williams v. Pro-Tec Inc., 908 F.2d 345, 347 (8th Cir. 1990). 